\title{
The design process of a reading comprehension manual
}

\section{El proceso de diseño de un manual de comprensión de lectura}

\section{Sergio Lopera Medina'}

Citation / Para citar este artículo: Lopera, S. (2015). The design process of a reading comprehension manual. Colomb. Appl. Linguist. J., 17(1), pp.130-141. Received: 23-Apr-2014 / Accepted: 28-Feb-2015

DOI: http://dx.doi.org/10.14483/udistrital.jour.calj.2015.1.a09

\begin{abstract}
Material design is an important part in the teaching practices. This article describes the process of material design of a foreign language (FL) reading manual for undergraduate students at Universidad de Antioquia (Medellín, Colombia). Action research was used as methodological guide to design the manual. Four in-service English teachers participated in the process of the design and they took into account issues such as the program of reading comprehension I, readings that contain cultural information and active background knowledge, reading with visual aids, and exercises that involved pre-, while-, and post-reading activities. As a result, a sample of a reading strategy is given in order to illustrate how teachers worked and designed the manual. Conclusions suggest that the process of designing a manual helped teachers understand their beliefs and practice in teaching reading in a foreign language.
\end{abstract}

Keywords: foreign language $(\mathrm{FL})$, material design, reading

\section{Resumen}

El diseño de material es una parte importante en las prácticas de enseñanza. Este artículo describe el proceso de diseño de material de un manual de lectura en lengua extranjera (LE) para los estudiantes de pregrado de la Universidad de Antioquia (Medellín, Colombia). La investigación-acción se utilizó como guía metodológica para el diseño del manual. Cuatro profesores de inglés participaron en el diseño del manual y tuvieron en cuenta elementos tales como el programa de comprensión de lectura I, lecturas que contuvieran información cultural y que activaran el conocimiento previo, lecturas con ayudas visuales y ejercicios que involucraran actividades de pre, mientras y post lectura. Como resultado se brinda una muestra de estrategia de lectura que ilustra como los profesores trabajaron y diseñaron el material. Las conclusiones sugieren que el proceso de diseño de este manual ayudó a los profesores a entender sus creencias y prácticas en enseñanza de lectura como lengua extranjera.

Palabras clave: lengua extranjera (LE), diseño de material, lectura

1 Escuela de Idiomas-Universidad de Antioquia, Medellín, Colombia. sergio.lopera@udea.edu.co 


\section{Introduction}

Language learning materials play an important role in order to create effective teaching and learning environments. Some teachers base their practices following a textbook, but they sometimes claim that a textbook does not fulfill both teachers' and learners' expectations (Núñez \& Téllez, 2008). Other teachers recognize the importance of developing their own instructional materials as they fit into their teaching contexts (Kuzborska, 2011). This article describes the process of designing an English reading comprehension manual for undergraduate students at Universidad de Antioquia in Medellín, Colombia. The article is divided into five parts: It begins with the literature review and then the methodology. Third, it describes the context, the process, and results of designing the manual with a sample of a reading strategy and some comments. Finally, some conclusions are outlined.

\section{Material design}

Núñez and Téllez (2009, p. 175) state that material design has been referred to by different terminology such as instructional materials design, course development, course books, instructional design strategies, and materials development. However, all of these names may have the same purpose: to help students learn a language. In fact, Tomlinson (2012) argues that materials for language learning are those which are used to facilitate language learning. Printed materials, course books, websites, videos, and readings are some of the different materials teachers use in their classes. Materials also vary as they inform students about the target language (informative), provide experience of the language use (experiential), help to make discoveries about the language (exploratory), guide to practice the language (instructional), or encourage use of the language (eliciting). The author points out that the ideal material should include all the previous elements.

Tomlinson (2012) highlights that material development is a very important part in the teaching processes. Material development can be seen as a field of academic study as it involves reflection, design, production, evaluation, adaptation, and piloting. Harwood (2010) also highlights the need to develop materials to suit the contexts in which they are going to be used. In fact, homemade materials help learners achieve greater relevance and engagement than commercial materials.

Howard and Major (2004) stress that there are discussions about the advantages and disadvantages when teachers design their own materials. Contextualization is regarded as an advantage due to the fact that teachers take into account their particular teaching contexts when they design their own materials. The low cost of homemade materials is another advantage. Teacher-produced materials are a good option for educational settings as they benefit both the institutions and students. A third advantage takes into account individual needs. Language classrooms are diverse not only in terms of location but also in terms of individual needs. Teacher-designed material can respond to the heterogeneity faced in the classroom and to the syllabus proposed by the institution. A teacher can design materials that have to do with specific students' needs, language level, and culture. Teachers can also make any decision as well as change when they design their own materials. Teachers can adjust materials when needed. Finally, homemade materials have a personal touch as designers tap into students' interests leading to personalization. When designers take into account interests, learning styles, and needs of students, it is likely to enhance their motivation and commitment to learning (Oxford, 2002). In short, when teachers design their own materials, they keep away from the one-size-fits-all imposed by commercial materials.

On the other hand, homemade materials have some disadvantages as well. The first is organization. Designers may lack a clear progression and may result in poor coherent direction. Another disadvantage is quality as teacher-produced materials may contain errors, be poorly designed, have unclear instructions, and lack clarity as well as durability. Teachers may also have inconsistent choices of texts. They may not have a clear idea 
about selecting or creating the right material for students. The last disadvantage is the time required to design homemade materials. Teachers are usually quite busy and do not find the time to design their own materials (Howard \& Major, 2004, p. 102).

\section{Reading}

Reading is one the most important language skills as it is used quite often not only for everyday life, but also for academic purposes. Lopera (2012) defines reading as "an interactive process in which the writer and the reader dialog through a text" (p. 81). The reader has to interpret the message posited by the writer and they both have to create coherent meaning. Lopera (2014, p. 90) supports that the reader needs to possess certain elements in order to understand the text: linguistic knowledge, background knowledge, and cognitive processes. Linguistic knowledge involves awareness about the language, that is, recognition of vocabulary, grammar structures, and tenses. Background knowledge has to do with the knowledge that the reader has about the topic he/she is reading. The prior knowledge of a topic helps readers understand the text. Finally, cognitive processes help readers memorize, predict, and interpret the text.

\section{Reading strategies}

Mikulecky and Jeffries (2004) support that reading strategies are useful as students build "on their already-established cognitive abilities and background knowledge" (p. 183). When teachers use reading strategies in language classrooms, students are guided to solve problems they face when reading. This approach also helps learners gain confidence and motivation (Lopera, 2014, 2012). Reading strategies may vary from simple ones such as scanning or guessing word meaning, to more complex ones such as summarizing or inferring.

Reading strategies are divided into two main categories: cognitive strategies and metacognitive strategies (Grabe \& Stoller, 2002; Carrell, Pharis, E Liberto, 1989; Block, 1986; Davis \& Bistodeau, 1993). Cognitive strategies are mental processes that are involved in order to achieve successful reading of a text and they are divided into two subcategories: bottom-up strategies and topdown strategies. Bottom-up strategies have to do with processing information at the sentence level (readers pay attention to the meaning of the sentence, analyze the details of the text and the syntax, among others). Top-down strategies deal with using background knowledge and schema to predict and make meaning from the text (readers skim, get the gist, and predict, among others).

Metacognitive strategies involve consciousness and awareness of what readers have learnt. Abromitis (1994) states that metacognitive abilities can "help students be more consciously aware of what they learn, situations where that knowledge may be used and the procedures for using it" (p. 4). Metacognitive strategies help monitor or regulate cognitive strategies (readers check to solve a problem, plan a move in a reading, monitor the effectiveness of an action, among others). Readers become more effective when they combine both cognitive strategies and metacognitive strategies.

\section{Methodology}

The process of material design described in this article followed a cycle of action research as teachers explored their practices. The teachers took into account their setting and supported their inquiry with theory and practice. This methodology is important and useful as action research is done by teachers and for teachers (Mikulecky, 2009 , p. 5). It is worth noting that the data is the process of designing the manual itself. Action research involves important aspects in teachers' practices such as reflection, awareness, planning, exploration, and changes (Burns, 1999; Selener, 1997). In fact, the aim of action research is to solve problems and always implies change (Tomal, 2010). Action research usually involves four stages for professional growth (Mertler, 2009; Tomal, 2010): 1. Planning: teachers identify the issue to be changed (they also develop questions, research methods, and develop a plan); 2 . Acting: teachers trial a change and follow a plan (they also collect 
evidence and question the process); 3. Observing: teachers analyze the evidence, discuss, and share findings; 4. Reflecting: teachers evaluate the cycle and implement the findings or new strategy. Finally, they revisit the process.

Teachers applied these four stages for the manual design as they: 1. Questioned and analyzed if their methodology as well as materials were appropriate (plan); 2. Read material about reading and designing and shared their own reading materials (acting); 3. Designed the reading material (observing); 4. Shared and evaluated the material themselves and made corrections. They finally revised the entire process (reflecting).

\section{Context}

\section{Language proficiency for students}

Undergraduate students have to show some proficiency in a foreign language in order to graduate at Universidad de Antioquia. They have three options to show proficiency: two reading comprehension courses (levels I and II, 80 hours each), integrated-skilled courses at Programa Multilingua2 (5 levels, 80 hours each), or a reading comprehension test. It is worth noting that the test simulates the standardized English language tests like the TOEFL, as it contains academic reading with multiple choice questions.

\section{The need to design a institutional manual for reading}

There were three groups of people who highlighted the need to design a manual for the course reading comprehension I: teachers paid by the hour (TPH) from Sección Servicios ${ }^{3}$, undergraduate students, and the academic committee from Sección Servicios. Regarding

2 Multilingua is a free program offered to outstanding undergraduate students at Universidad de Antioquia. They have eight language options to study (English, French, Italian, Portuguese, Chinese, Japanese, Turkish, and German).

3 Sección Servicios is part of the School of Languages at Universidad de Antioquia. It serves reading comprehension courses as well as integrated skilled courses to both graduate and undergraduate students. the first group, some TPH consistently expressed the need to construct a manual for their teaching practices in academic meetings as they sometimes questioned if the material as well as the methodology were appropriate. They believed this material could be very useful because it would be institutionalized and this might lead to work with reading strategies in a uniform way; some teachers even volunteered to construct the manual. Undergraduate students also supported the need to have a manual. In some of the reports completed by students in order to improve teaching practices at the end of the courses, students suggested having a manual as most TPH work with isolated photocopies, fliers, or units of books. They also expressed that the quality of the material was not that good and they sometimes did not feel willing to read because the readings were not motivating.

The last group was the academic committee from Sección Servicios. This committee has observed that some TPH teaching practices rely mainly on translation or grammar exercises and they do not involve cognitive strategies and metacognitive strategies even though they are core in reading. The committee considered the manual as a good alternative in order to homogenize the teaching practices and this would improve the learning processes for undergraduate students.

Finally, one of the members of the academic committee from Sección Servicios decided to lead the idea of designing a manual for level I in reading comprehension. In fact, there was a job opening for full time professors at Universidad de Antioquia in 2008, and he submitted a proposal that had to do with designing a foreign language reading manual. The proposal was accepted, and he then presented it to teachers at Seccion Servicios. As a result, three more professors volunteered to participate in the design process.

\section{The team to design the manual}

Four in-service teachers participated in the design of the manual: two females and two males. One of the females had just started her career to teach reading and was quite motivated to begin the design. The other one had more than 10 years of 
experience teaching reading in a foreign language. Regarding the males, one of them was retired and had more than 30 years of experience teaching reading. The other one had about 15 years of experience teaching reading and was in charge of leading the process. All teachers were TPH except the teacher in charge of the process who was a fulltime professor and they all worked at Universidad de Antioquia.

\section{The process and results of designing the manual}

The teachers began by discussing several articles about teaching reading. From these texts, they identified core elements of an academic reading program that needed to be taken into account. These included lower-level processes (vocabulary and grammar recognition); higherlevel processes (comprehension and interpretation of a text); metacognitive factors that involve knowledge of cognition (readers are aware of the reading strategies they use) and regulation of cognition (readers choose appropriate or more effective reading strategies in order to have a better understanding of a text); task design following the format of pre-reading (help learners activate background knowledge), while-reading (guide the readers to analyze the text), post-reading (help learners verify or expand the knowledge acquired in the text); principles to teach reading (students' interests, students' own selection of materials, reading practice, individual and silent reading, teacher`s orientation, teacher's sample); assessment practices that involve alternative methods (journals, observation, self-assessment, peer assessment, homework) as well as traditional ones (tests, test questions - multiple choice questions, completion tasks, open/ended questions) (Aebersold \& Lee Field, 1997; Arias \& Maturana, 2005; Areiza, 2013; Alyousef, 2005; Brown, 2001; Carrell, 1984; Correia, 2006; Day \& Bamford, 2000; Dubin \& Bycina, 1991; Grabe \& Stoller, 2002; Janzen, 2005; Lopera, 2014; McDonough \& Shaw 1993; Nunan, 1999; Ommagio, 1993; Picón, 2012; Royer, 2004; Ur, 1999; Villanueva de Debat, 2006; Williams, 1986).
They also discussed articles regarding the design and selection of teaching materials. They considered important elements such as authentic material (produced to communicate), adapted material (produced to teach); types of texts (informative, experiential, instructional, exploratory, eliciting), and material adaptation (adding, omitting, modifying, simplifying, reordering) (Aebersold E Lee Field, 1997; Brown, 2001; Howard \& Major, 2004; McDonough E Shaw, 1993; Nunan, 1999; Núñez \& Téllez, 2009; Tomlinson, 2012, 1998). Moreover, they analyzed materials that contained readings with exercises (Mikulecky \& Jeffries, 2004; Richards, 2005; Richards \& Eckstut-Didier, 2003; Smith \& Mare, 1999; Werner $\varepsilon$ Spaventa, 2002) and visited some web sites to analyse their design ${ }^{4}$. Subsequently, the designers discussed their teaching experiences and exchanged the materials they had used in their classes. Finally, they began the process of designing the manual taking into account the following academic issues:

1. The three stages for reading activities: prereading activities, while-reading activities, and post-reading activities (Lopera, 2012). Pre-reading activities were intended to construct background knowledge (Phillips, cited in Omaggio, 1993). In this stage, teachers designed activities such as vocabulary introduction, looking at visuals, and previewing the text. While-reading activities were intended to ask students to have immediate contact with the reading. Asking for the main idea, guessing, and making inferences are some examples. Postreading activities were intended to verify and expand knowledge acquired during the reading. Identifying the author's purpose, discussing the author's line of reasoning, summarizing the text are some examples of this stage. It is worth noting that the academic group designed all activities and created most of the readings.

\footnotetext{
4 http://www.english-zone.com/vocab/vic01.html, http://www.readingtransformations.com/members_area/ IntroNoPreviewingEx.html, http://www.englishdaily6̄26.com/ sentence_connectors.php?005, http://web2.uvcs.uvic.ca/elc/ StudyZone-200/reading/xmas1.htm, http://academic.cuesta. edu/acasupp/as/308.HTM, http://www.daltonstate.edu/faculty/ mnielsen/patterns practice_1.htm, http://web2.uvcs.uvic.ca/elc/ studyzone/570/pulp/hemp1.htm,
} 
2. Two forms of assessment: formative and summative (Areiza, 2013; Picón, 2012). The former deals with assessing learning as well as teaching during the process. The results tell the teacher what he/she must do/adjust during the course (at the beginning, in the middle, etc.). The latter refers to an assessment at a specific time and it usually occurs at the end in order to evaluate what students have learnt.

3. The following general considerations for the design of the manual:

- Readings must contain visual aids

- The reading strategies are linked to the program of reading comprehension $\mathrm{I}^{5}$ proposed by Sección Servicios

- Some grammar topics need to be covered in this manual as they are proposed in the program of reading comprehension I. However, they are a complementary part of the reading strategy. The grammar topics help readers recognize linguistic elements. These grammar topics are going to be under the heading "grammar corner"

- The purpose of reading activities is to help readers understand the text

- Some texts should deal with cultural information and activate background knowledge

- The aim of the topics, strategies, and exercises presented in this manual is to help learners develop their capacity to understand different texts as well as topics. The aim is to develop a "universal reader": a reader who has the ability to read different kinds of reading materials

- The manual must contain academic language in order to familiarize students with the formal organization of texts

- Websites are suggested for further practice

- Each topic needs to have a goal in order to inform readers of the purpose of the theme

- The exercises as well as the readings can be adapted. Some techniques such as adding,

5 The program of reading comprehension I contains the following topics: guessing word meaning, scanning, skimming, topic, main idea, referents, and patterns of organization. It also contains grammar topics (verbal tenses, modal verbs, passive voice, comparison, superlatives, and basic structure of a sentence) affixes, and dictionary use. modifying, rewriting, subtracting, or simplifying could fit the purpose (McDonough $E$ Shaw, 1993)

- The teacher can bring other readings as well as exercises in order to recycle or reinforce the reading topics

- The exercises of this manual try to avoid translations. The aim is to understand the readings using reading strategies

- Dictionary use is important in the process of understanding readings. However, this use is going to be lessened as students are guided in applying reading strategies

- This manual aims at intensive reading: teachers guide the process, and it is usually given in classrooms. Nevertheless, the teacher of the course may involve extensive reading, too: reading individually and silently for the purpose of enjoyment (Villanueva de Debat, 2006)

- There must be an answer key in order to help both teachers and students with the analysis and application of the exercises

In order to verify the academic production of the manual, designers decided to take into account the following strategies:

- A proof reader must correct the manual

- Designers will pilot some units of the manual during the design

- The academic committee from Sección Servicios will assess the manual and give feedback to designers

- As soon as the academic committee from Sección Servicios approves the manual, designers will ask an outsider to pilot the manual

Finally, the process of designing the manual began in September 2009 and was completed in November 2012.

\section{Results: A sample of a reading strategy}

The following sample contains part of the reading strategy "scanning" as a product of teachers' design. It is not given completely due to space limitations: 


\section{Scanning}

Goal: the student is able to find specific information in a text in a rapid manner in order to extract specific information about the text

Scanning is a reading strategy in which the reader searches for a word, a number, a name, a place, a date, or a key idea. Usually, the reader knows in advance what he/she is looking for. Scanning is a rapid process in which the objective is to find what the reader needs (Mikulecky $\mathcal{E}$ Jeffries, 2004).

\section{Example}

Read the following paragraph and find the day when the person is going to see a movie
Well, I am very busy these days but you know how much I like going to the movies. I think I can 't make it on Thursday or Friday. On Saturday I have to go shopping and I have to visit my family in Toronto. Sunday is the perfect day to go because I don 't have to do many things. Besides, it is my day off. Would you like to go with me?

The answer to the previous exercise is Sunday. Did you have to understand the complete text? Maybe not, you just had to look for the day to go to the movie.

The following (wh) questions guide the reader to look for a specific detail:

\begin{tabular}{cccc}
\hline Where & What & When & Why \\
Who & How & Which & How much \\
How many & How long & How often & What time \\
\hline
\end{tabular}

\section{Reading}

Vocabulary introduction

Give the possible meaning of the underlined words in the spaces given.

a. The antique car parade is a popular event in "Las Fiestas de las Flores"

b. The sky becomes beautiful with the fireworks at nights because the lights and the colors decorate the sky.

c. I have food, a house, and I am in good physical shape. I have good welfare

\section{National Holidays in the United States}

The United States has many holidays and they come from either its history or religious traditions. For example, Independence Day, on July 4, represents one of the most important holidays for Americans. On this day, Americans celebrate their independence from the Kingdom of Great Britain in Europe. Parades, fireworks, and reunions are some of the activities Americans do in order to celebrate the anniversary of the Declaration of Independence. Another example is Thanksgiving. On the fourth Thursday in November, Americans give thanks for their welfare and remember the legacy of colonization European people, and the English pilgrims, left in America. Family gatherings and meals are the most common activities on this day.

The following chart compiles the most important holidays in the United States: 
Chart 1. Important holidays in the United States

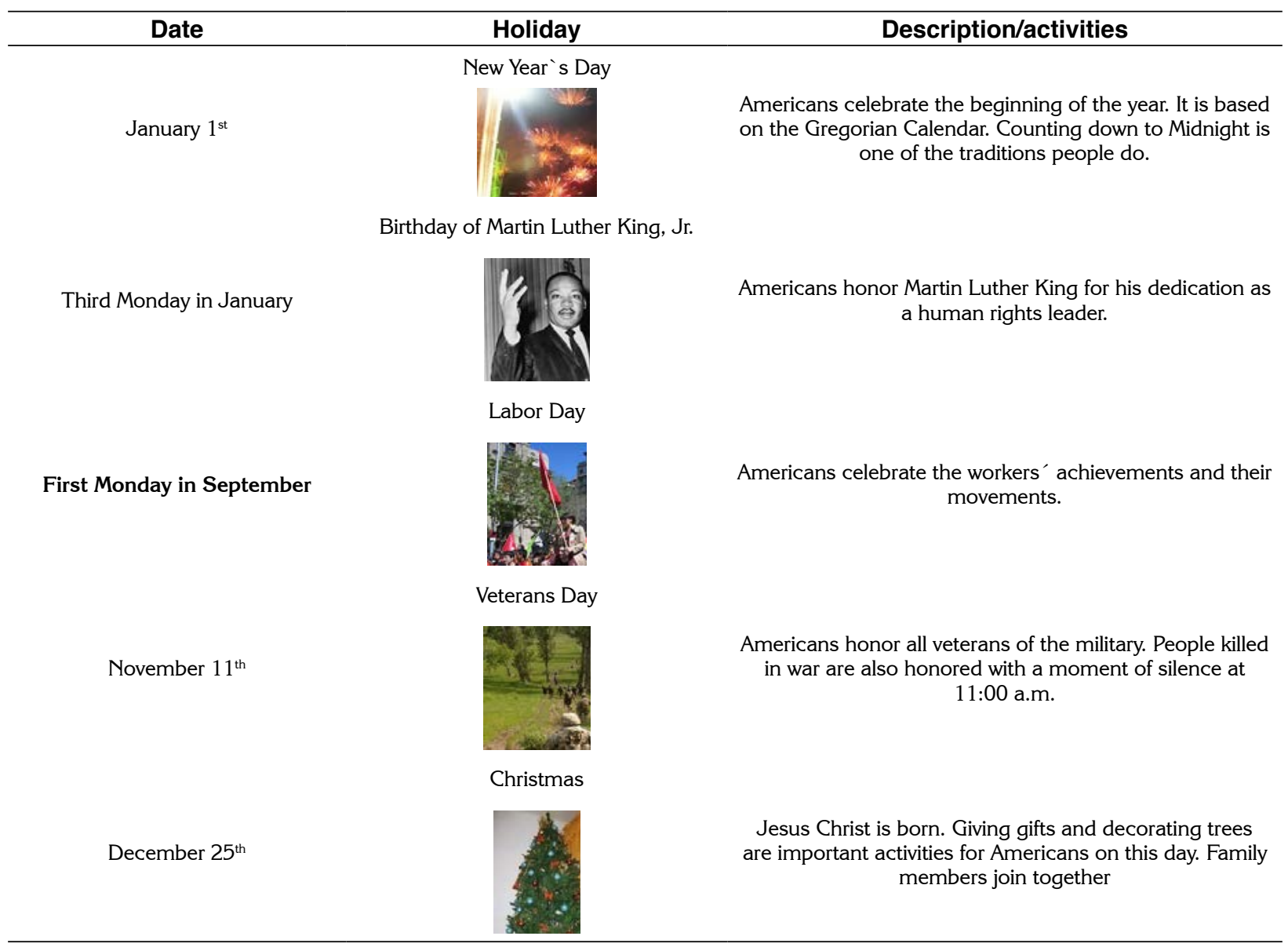

Images taken from Wikipedia www.wikipedia.org/

Answer the following questions based on the previous reading

Where do holidays come from?

There are seven holidays mentioned above, what are they?
What day is the memorial for people who died in wars?

There are three holidays in which families get together, what are they?

I am planning to cook turkey for some people, which holiday is the most appropriate to have turkey? 


\section{Exercise 2}

Reading comprehension exercises

1. Valentine's Day is celebrated on February 14. The day is named after a Christian martyr called Valentine. According to this statement Valentine's Day is a:

a. History day

b. Religious day

c. Both history and religious day

2. Where can you place Valentine's Day?

a. Between New Year Day and the birthday of Martin Luther King, Jr.

b. Between the birthday of Martin Luther King, Jr. and Independence Day

c. Between Christmas and New Year's

3. Europe was involved in each of the following holidays except:

a. Independence Day
b. Thanksgiving
c. Labor Day

4. The word "they" (first line) refers to
a. Holidays
b. Americans
c. Religious traditions

\section{Reading practice}

You can practice "scanning" in the following web sites:

http://web2.uvcs.uvic.ca/elc/StudyZone/200/ reading/xmas1.htm

http://web2.uvcs.uvic.ca/elc/StudyZone/200/ reading/smicat1.htm

http://www.elearningplace.co.uk/9351/taster/ tasterscanexercise.php?sess_key

http://web2.uvcs.uvic.ca/elc/studyzone/570/ pulp/hemp2.htm

\section{GRAMMAR CORNER}

\section{Simple present}

The simple present tense often refers to actions or situations that do not change frequently. It is used to describe habits or routines, to express opinions, or to make general statements of fact. The simple present can also be used to refer to the future. (Werner $\mathcal{E}$ Spaventa, 2002). Note: verbs in present (I work, she lives, I am) and adverbs such as today, now, at the moment; and auxiliaries (do, does, can) can help you recognize this tense.

Examples

Tissue engineering is the use of a combination of cells, engineering and materials methods.

Tissue engineering utilizes living cells as engineering materials.

\section{Exercise 1}

Underline the verbs that are in the simple present in the following sentences:

a. While most definitions of tissue engineering cover a broad range of applications...

b. The tissues involved require certain mechanical and structural properties for proper functioning.

c. From solid tissues, extraction is more difficult.

d. Temperatures digest the matrix faster

\section{Exercise 2}

Fill in the blank spaces with the correct form of the verb (parenthesis) and also answer the questions below.

Tissue engineering (substitute) a whole organ. It also or

(restore, maintain) the tissue function of a specific organ. Tissue engineering (be) also the understanding of the principles of tissue growth, and applying this to produce functional replacement tissue for clinical use. Tissue engineering __ (have) some strategies that (involve) multidisciplinary fields.

Scientific companies (fabricate) biomaterials, stem cells that ___ (combine) extracellular matrices for tissues. Some companies _or ___ (use, create) natural or synthetic material.

\section{Exercise 3}

Answer the following questions based on the previous paragraph

a. Tissue engineering involves different aspects, what are they?

b. What do companies create? 
c. Is tissue engineering a field that works alone? Why?

\section{Grammar practice}

You can practice "simple present" in the following web sites:

http://www.mansioningles.com/gram39.htm http://www.englischhilfen.de/en/exercises_ list/alle_grammar.htm

http://www.ego4u.com/en/cram-up/gramma http://www.saberingles.com.ar/curso/ lesson02/06.html

http://www.saberingles.com.ar/curso/ lesson02/08.html

\section{Recycling activity}

The teacher will bring an activity in order to recycle this topic

Self-assessment ${ }^{6}$

Mark the option that supports your selfassessment criteria during the reading comprehension course (5 the highest).

Linguistic level:

\begin{tabular}{|c|c|c|c|c|c|c|}
\hline & I... & 1 & 2 & 3 & 4 & 5 \\
\hline 1 & Read to understand the whole reading & & & & & \\
\hline 2 & Use my background knowledge in the readings & & & & & \\
\hline 3 & Use the context in order to interact with the reading & & & & & \\
\hline
\end{tabular}

Attitudinal level:

\begin{tabular}{|c|c|c|c|c|c|c|}
\hline & I... & 1 & 2 & 3 & 4 & 5 \\
\hline 1 & Take part in all assigned activities in class & & & & & \\
\hline 2 & Take part in all assigned activities out of class & & & & & \\
\hline
\end{tabular}

Some comments about the sample

This sample is the product of the academic reasoning of four teachers. The sample involves vocabulary and grammar recognition (vocabulary introduction, grammar corner: lower-levelprocesses), reading comprehension and interpretation (open questions and multiple choice questions: higherlevel processes), awareness of the use of the strategy (scanning: metacognitive factors). Teachers also considered assessment practices (reading comprehension exercises and self-assessment: alternative and traditional methods), stages to guide the readers to understand the text (pre-, while-, and post-reading activities), and readings that contain visual aids (images for the holidays).

\section{Conclusions}

The production of a FL reading manual was an effort of four in-service teachers who wanted to have homemade material. For the design of the manual, teachers considered that it should include a cultural topic (holidays: informative), experience of the language use (reading comprehension exercises: experiential), discovery of the language (exploratory), and language practice (instructional/ eliciting). They also considered the program of reading comprehension I, reading with visual aids, and exercises that involved pre-, while-, and postreading activities. It is important to highlight that the manual may become a useful tool depending on the objectives or methodology the teacher has to use

6 This instrument was administered in Spanish. 
and it is she/he who gives a pedagogical touch in her/his teaching contexts.

The design of this manual helped teachers become more aware of their own teaching and also helped them understand their beliefs and practice in teaching reading in a foreign language. In fact, teachers realized that reading has to do with cognitive strategies (exercises that help readers understand the text), metacognitive strategies (awareness of the use of the strategy: scanning), and linguistic knowledge (grammar corner). Another important aspect was assessment. Teachers are now aware of including both formative and summative practices when designing material. The sample of a reading strategy given above could be seen as part of their awareness and agreement toward teaching reading as a foreign language. However, this reading strategy designed for reading comprehension I at Sección Servicios (Escuela de Idiomas - Universidad de Antioquia) should be seen as another option or tool for teachers as Universidad de Antioquia has the concept of "Cátedra Libre" and teachers cannot be forced to use it. Finally, it would be interesting to see the academic impact of this manual on students' reading outcomes by carrying out further research.

\section{References}

Abromitis, B. (1994). The role of metacognition in reading comprehension: limplications for instruction. Literacy Research Report, 19, 1-31.

Alyousef, H. (2005). Teaching reading comprehension to ESL/EFL learners. The Reading Matrix, 5(2), 143154.

Areiza, H. (2013). Role of systematic formative assessment on students' views of their learning. PROFILE, 15(2), 165-183.

Arias, C., E Maturana L. (2005). Evaluación en lenguas extranjeras: Discursos y prácticas. Ikala, Revista de Lenguaje y Cultura, 16, 63-94.

Aebersold, J., \& Lee Field, M. (1997). From reader to reading teacher. Cambridge: Cambridge University Press.

Block, E. (1986). The comprehension strategies of second language readers. TESOL Quarterly, 20(3), 63-490.

Brown, D. (2001). Teaching by principles. United States: New York: Longman.
Burns, A. (1999). Collaborative action research for English language teachers. London: Cambridge University Press.

Carrell, P., Pharis, B., \& Liberto, J. (1989). Metacognitive strategy training for ESL reading. TESOL Quarterly, 23, 647-678.

Carrell, P. (1984). Schema theory and ESL reading classroom implications and applications. Modern Language Journal, 68(4), 332-342.

Correia, R. (2006). Encouraging critical reading in the EFL classroom. English Teaching Forum, 1, 16-19.

Davis, J. N., \& Bistodeau, L. (1993). How do L1 and L2 reading differ? Evidence from think aloud protocols. The Modern Language Journal, 77(4), 459-471.

Day, R., \& Bamford, J. (2000). Extensive reading in the second language classroom. Cambridge: Cambridge University Press

Dubin, F., E Bycina, D. (1991). Academic reading and the EFL/ESL teacher. In M. Celce-Murcia (Ed.), Teaching English as a second or foreign language (pp.195215). New York: Heinle \& Meinle publishers.

Grabe, W., \& Stoller, F. (2002). Teaching and researching reading. England: Pearson Education.

Harwood, N. (2010). Materials in ELT: Theory and practice. Cambridge: Cambridge University Press.

Howard, J., \& Major, J. (2004). Guidelines for designing effective English language teaching materials. The TESOLANZ Journal, 12, 50-58.

Janzen, J. (2005). Teaching strategic reading. In J. Richards \& A. R. Will (Eds.), Methodology in language teaching. An anthology of written practice (pp. 287295). Cambridge: Cambridge University Press

Kuzborska, I. (2011). Teachers' decision-making processes when designing EAP reading materials in a Lithuanian university setting. Journal of English for Academic Purposes, 223-237.

Lopera, S. (2012). Effects of strategy instruction in an EFL reading comprehension course: a case study. PROFILE, 14(1), 79-90.

Lopera, S. (2014). Motivation conditions in a foreign language reading comprehension course offering both a web-based modality and a face-to-face modality. PROFILE, 16(1), 89-104.

McDonough, J., \& Shaw, C. (1993). Materials and methods in ELT. Oxford: Blackwell.

Mertler, C. A. (2009). Action research (second edition). Los Angeles, London, New Delhi: SAGE Publications.

Mikulecky, B., \& Jeffries, L. (2004). Reading power. United States: Pearson, Longman. 
Nunan, D. (1999). Second language teaching and learning. Boston: Heinle \& Heinle Publishers.

Núñez, A., \& Téllez, M. (2009). ELT materials: The key to fostering effective teaching and learning settings. PROFILE, 11(2), 171-186.

Núñez, A., \& Téllez, M. (2008). Meeting students' needs. Enletawa Journal, 1, 65-68.

Omaggio, A. (1993). Teaching language in context. Boston: Heinle $\&$ Heinle Publishers.

Oxford, R. (2002). Sources of variation in language learning. In R. B. Kaplan (Ed.), The Oxford handbook of applied linguistics (pp. 245-252). New York: Oxford University Press.

Picón, E. (2012). Promoting learner autonomy through teacher-student partnership assessment in an American high-school: a cycle of action research. PROFILE, 14(2), 145-162.

Richards, J. (2005). Interchange (3rd ed.). Cambridge: Cambridge University Press.

Richards, J., \& Eckstut-Didier, S. (2003). Strategic reading. Cambridge: Cambridge University Press.

Royer, J. (2004). Teaching reading comprehension skills. Retrieved from http://educator.readingsuccesslab. com/Tips/TeachingReadingComprehensionSkills. html
Selener, D. (1997). Participatory action research and social change. New York, NY: The Cornell Participatory Action Research Network.

Smith, L., \& Mare, N. (1999). Insights for today. Boston: Heinle $\&$ Heinle Publishers.

Tomal, D. (2010). Action research for educators (2nd edition). Lanham MD: Rowman $\varepsilon$ Littlefield Education.

Tomlinson, B. (1998). Materials development in language teaching. Cambridge: Cambridge University Press.

Tomlinson, B. (2012). Materials development for language learning and teaching. Language Teaching, 45(2), 143-179.

Ur, P. (1999). A course in language teaching. Cambridge: Cambridge University Press.

Villanueva de Debat, E. (2006). Applying current approaches to the teaching of reading. English Teaching Forum, 1, 2006.

Werner, P., \& Spaventa, L. (2002). Mosaic 1, Grammar. New York: McGraw-Hill.

Williams, R. (1986). "Top ten" principles for teaching reading. ELT Journal, 40 (1), 42-45. 